\title{
41919
}

\section{Body, ancestry, and ecstasy: reading Rotimi Fani-Kayode's photographs in contemporary times}

\author{
Jânderson Albino Coswosk
}

\begin{abstract}
:
This article addresses different appropriations and representations of the lives of Black gay men, from the African diaspora and with transits established in late twentieth-century Europe, concerning the photographic essays of the Nigerian artist Rotimi Fani-Kayode (1955-1989), who lived for a long time in late twentieth-century England. This work seeks, through the analysis of the transit experienced by the artist between Africa and Europe, as well as in the power of the most diverse languages used in his photo essays, to give a contemporary reading of the male homosexual black body based on an eroticism and spirituality that escape the hegemonic and heteronormative narratives that have long imprisoned these ways of seeing and narrating Black gay men in the enclosure of racial tensions, homophobic crimes and conflicts of other order of sexuality.
\end{abstract}

Keywords: black gay body; photographic narratives; affection; endurance.

\section{Resumo:}

O presente artigo aborda diferentes apropriações e representações da vida de homens negros gays, oriundos da diáspora africana e com trânsitos estabelecidos na Europa do final do século XX, a partir dos ensaios fotográficos do artista nigeriano Rotimi Fani-Kayode (1955-1989), que viveu durante muito tempo na Inglaterra do final do século XX. Busca-se, no trânsito vivido pelo artista entre África e Europa, bem como na potência das mais diversas linguagens empregadas em seus ensaios fotográficos, conferir uma leitura contemporânea sobre o corpo negro homossexual masculino a partir de um erotismo e uma espiritualidade que escapam às narrativas hegemônicas e heteronormativas, que durante muito tempo aprisionaram esses modos de ver e narrar o homem negro gay na clausura das tensões raciais, dos crimes de caráter homofóbico 
que ainda marcam ambos os espaços geográficos em evidência e de conflitos da ordem da sexualidade.

Palavras-chave: corpo negro gay; narrativas fotográficas; afeto; resistência.

"How do I live free in this black body?" (Coates, 2015: 12). In 2015, this question from African American journalist Ta-Naesi Coates, who opens his book Between the world and me, started a huge debate about the frequent police violence against Black men and women in the United States. By borrowing the style of civil rights activist and writer James Baldwin, Coates rekindles a seamless dialogue, begun in the mid-1960s, by his predecessor, in The Fire Next Time (1963), about violence against the African-American population by the police, through institutionalized racism that produced the physical and symbolic annihilation of black bodies.

It is from the effervescence of this debate and the attempt to overcome these issues that young Nigerian photographer Rotimi Fani-Kayode, then 21, becomes contaminated by leaving England to study at Georgetown University in Washington, DC. Infected by the post-Civil Rights Movement spirit that hovered in the United States at the time he moved there, as well as the black gay scene emerging in Washington, Chicago, and New York. These ingredients gave Fani-Kayode a certain lap and warmth, considering that he came from a geographical space that was gradually ceasing to be called the British Protectorate, and that had to deal shortly thereafter with the still open wound caused by the Biafra Civil War, from which his family moved away, seeking refuge in England. FaniKayode witnessed the insurgency of the black gay scene in the rubble of racial segregation in the United States, where he, too, could experience his homosexuality more freely.

Far from the perspective of a quest for selfhood, Fani-Kayode clung to the tracks of an identity that was no longer conceived as African but at the same time was neither European nor American. It was a mixture of them all, as it sought its African ancestry through Yoruba culture and the body, linking it to photographic experimentation based on his sexuality.

Fani-Kayode had to shape his identity with the dilemma of what it means to be Nigerian. A nation-state featuring the language of the colonizer mixed with the native languages, surrounded by ethnic-religious conflicts and, as a result, serious problems still involving LGBTQ people today. Nigeria remains in the contemporary clash between maintaining the roots of the organized states before the invasion of the British Empire, as well as their influences on what it became after the Biafra Civil War. 
When it comes to violence against LGBTQ's, Westernized viewpoint imposes an even greater burden on the reception and permanence of these individuals in their country of origin. They still continue to live under police and family violence because of the dissent of their bodies, which do not fit into the heterogeneous order of the colonial system, and the establishment of a nation state already exhausted in its initial model, organized within the male-female binomial. In January 2014, Nigeria instituted the Same Sex Marriage Prohibition Act, which banned same-sex marriage, contributing to the intolerance against sexual minorities in Nigerian society (Akinwotu, 2018, March 30).

The feeling of not being able to develop his art in the 1980s in his homeland was part of the drama experienced by Rotimi Fani-Kayode, although he could not return to Nigeria anyway:

It has been my destiny to end up as an artist with a sexual taste for other young men. As a result of this, a certain distance has necessarily developed between myself and my origins. The distance is even greater as a result of my having left Africa as a refugee over 20 years ago. On three counts I am an outsider: in matters of sexuality; in terms of geographical and cultural dislocation; and in the sense of not having become the sort of respectably married professional my parents might have hoped for. Such a position gives me a feeling of having very little to lose. It produces a sense personal freedom from the hegemony of convention (Fani-Kayode, 1996: 5).

Rotimi Fani-Kayode's aesthetic project had the male and black gay body as its support and the ecstasy as the link between the material and spiritual plane, between sexuality and spirituality, between his Yoruba cultural heritage and his encounter with the European world. In the words of Kobena Mercer,

his kaleidoscopic vision, filtering African and European elements through his camera's optic nerve, and his passionate pursuit of carnal visual pleasure, reveal instead a heightened encounter with the emotional reality of the flesh in which it is precisely the ego's ecstatic loss of identity that is celebrated (Mercer, 1996: 109).

In Fani-Kayode's photograph, the predominance of naked male black bodies, "smallpox gods, transsexual priests and desirable black men" (Fani-Kayode, 1996: 9) is present due to their transfiguration between ecstasy and the rescue of Yoruba ancestry that permeates between props and body poses (Figure 1).

Precisely because of such a "kaleidoscopic view", derived from the experience between three continents - Africa, Europe and North America -, the helplessness that displacement causes in the migrant, the attempt to live simultaneously between worlds and to live the transformations that occurred in the 1960s, 1970s and 1980s, is that FaniKayode's life and work were never confined to the comfort and security of an identity, for 
they were not limited to labels that imprisoned them to one or another "national identity", or to the "African and Black being", either to homosexuality as well, all of them confined to immobility and exoticism.

From an opening characterized by the emergence of the postmodern and anti-colonial wars in African territories, the diaspora and the experience of sexuality in transit stand as pillars for the reflection of the roots of Kayodian photography under the "domain of the sacred" (Mercer, 1996: 110), as noted in his first Black Male / White Male (1987) photo collection, followed by the publication of his inaugural essay Traces of Ecstasy (1996).

Despite having had only one solo exhibition in life, in six years of his career, FaniKayode's work has appeared in numerous group shows, demonstrating how much his work has traveled through various spaces and how it has impacted the panorama of British visual culture of the 1980s, when he founded and assumed the chairmanship of the Autograph - Association of Black Photographers, established contacts with artists from within and outside the British ambience, had several of his photographs used in queer anthologies of literature and art criticism, and became sort of a spokesmen of queer culture.

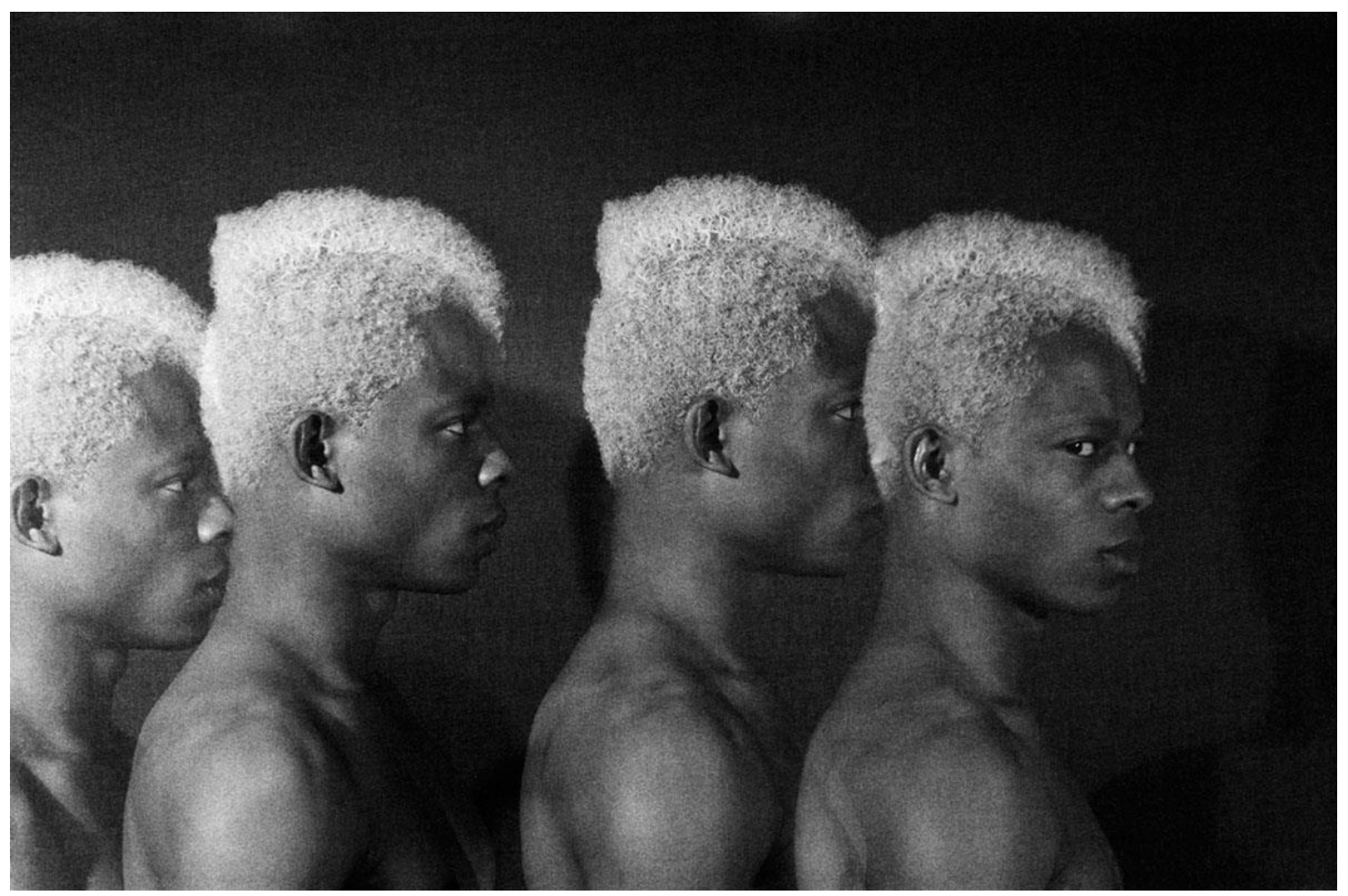

Figure 1: Rotimi Fani-Kayode, Four Twins, 1985. @ Rotimi Fani-Kayode / Autograph ABP. Courtesy of Autograph ABP. 
The fact that the body, in his work, becomes a place of translation and metaphor, Rotimi Fani-Kayode engages in a "transatlantic formation of a black gay cultural diaspora" by assuming the role of a "migrant translator", in the terms of Kobena Mercer (1996: 1-5). A curious and contemporary repercussion of Kayode's influence on Image Studies brings us straight to the exhibition titled after his inaugural essay, Traces of Ecstasy, organized in 2016, but outside Western eyes. It was the first time his work had been exhibited in Africa at the Iziko South African National Gallery museum at the time, 25 years after the Nigerian photographer's death. In the words of Rebecca Steel (2016, December 28), museum critic, "the photographs of Rotimi Fani-Kayode have allowed us to re-evaluate what constitutes black African male sexuality".

In partnership with the Autograph ${ }^{1}$, the museum featured Kayode's most iconic images, including its inaugural publication, Black Male / White Male, as well as others published by Gay Men's Press or by Ten.8, such as Nothing to Lose and Bodies of Experience, in whose work he had the unconditional partnership of his companion and lover Alex Hirst. If the exhibition had taken place in Africa in the 1980s, as Fani-Kayode himself puts it,

If I ever managed to get an exhibition in, say, Lagos, I suspect would break out. I would certainly be charged with being a purveyor of corrupt and decadent Western values (Fani-Kayode, 1996: 9)².

Faced with a ban on homosexual union in several African countries, the exhibition becomes a milestone in the continent's contemporary times, given the huge number of requests for refuge from men and women from Africa to the West due to homosexuality seen as a crime in Cameroon, Chad, Egypt, Nigeria, Ghana, Uganda, among other African nations (UNHCR, 2019). In addition, the exhibition proposes to read the images cited as objects that promote homosexual affection and empathy in contemporary times, abandoning the hegemonic "advertising" purposes of dissemination of violence and brutality to which these bodies are affected daily.

Such images were exhibited without a premeditated temporal linearity or hierarchization of bodies or colors in portraits, nude studies and staged black and white paintings, in a discontinuous and decentralized genealogy, typical of Kayode's work. Randomly, Traces of Ecstasy uses Kayode's method to bring out a photographic language that transitions between the universe of black-African and male sexuality and reconstituted Yoruba religious signs in the West, but outside of Anglophone visual colonial regimes. Identification with the collection of Yoruba Africanity is immediate, either through

\footnotetext{
${ }^{1}$ Some of the archives are at Tate or Hales Gallery in London.

2 For more information concerning Fani-Kayode's images and their impact on African audiences, see Rebecca Steel (2016, 28 December).
} 
ritualistic practices and religious symbols, through body paintings, the elements of nature that compose them, or through the use of masks, an object that, in Yoruba culture, is a link between the carnal and the spiritual plan, not something to hide a kind of secret (Figure 2).

The hybridization of such elements is visible through the appropriation of Western objects and garments, which reveal the direct influence of Christianity in Africa, as well as the burden of slavery (Figure 3). However, such elements produce an interruption, a suspension in the reading of images, either by the free pleasure and enjoyment of bodies historically expropriated from their histories, or by the complete nudity (or not) of their limbs, or even by the friction of the muscles in contact that express the carnal desire among men (Figure 4). The symbiosis between creator and creation (the photographer and the models) evades the anthropometric photographic practices of the nineteenth century, which "transform(ed) the living into the quiet, the subject into the object", highlighting "the difference of power established between the observed and the observer" (Matos, 2014: 45-46). 


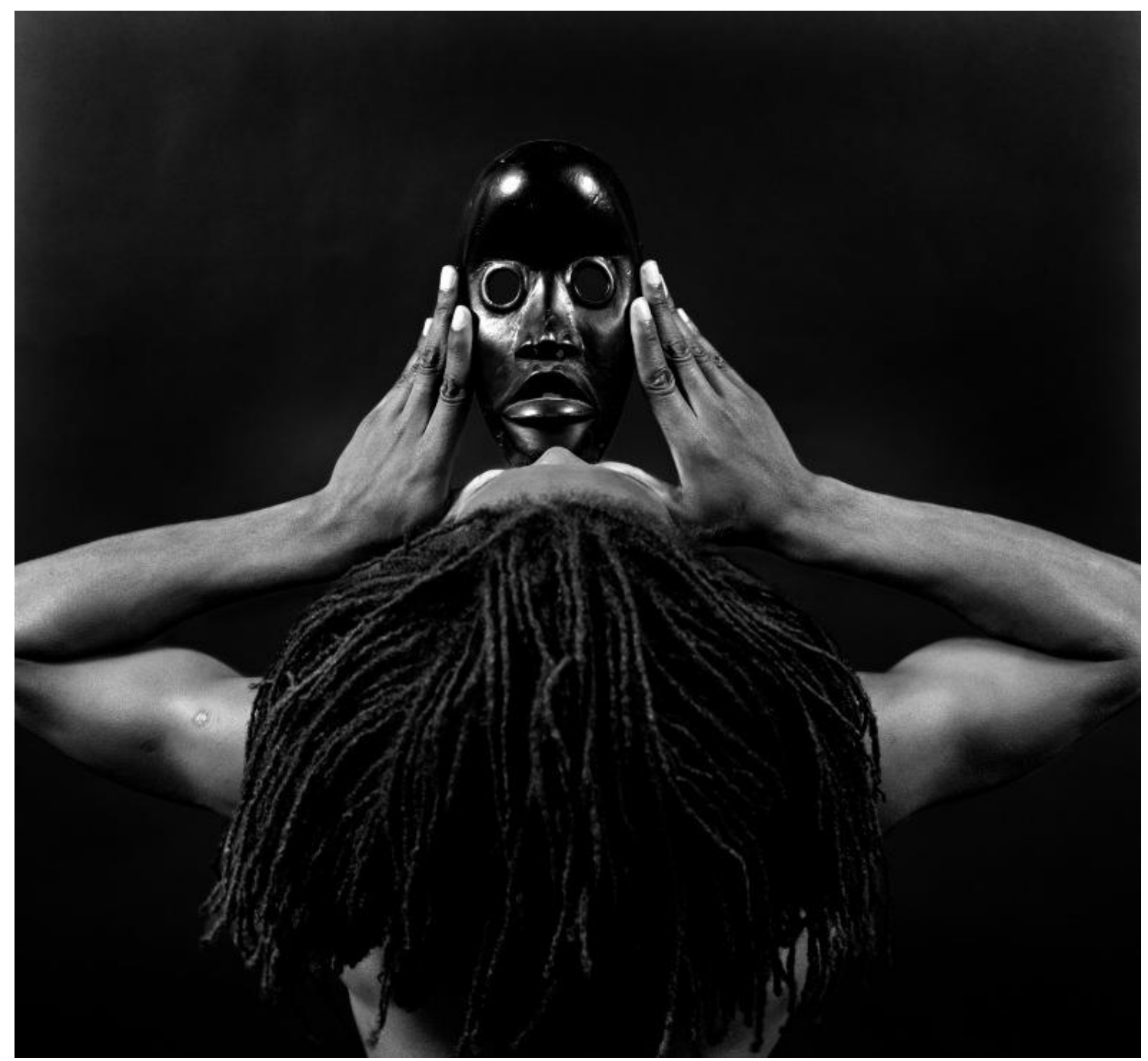

Figure 2: Rotimi Fani-Kayode, Dan Mask, 1989. @ Rotimi Fani-Kayode / Autograph ABP. Courtesy of Autograph ABP.

The freedom of bodies in their exposure, materiality and plasticity distances them from fetish and hyper sexualization, from the control and freezing of bodies, endowing them with their own domain, beyond erotic desire. The helplessness of those who contemplate them, when with masks, for example, puts the viewer in a distant terrain of Cubist primitivism, forcing them to build another reading of the bodies that face them.

Similarly to Aimé Césaire, Fani-Kayode's "return to the home continent" through his work, even after death, brings us the possibility of returning to the unavoidable and so present invitation of the writer Chinua Achebe, on the eve of Nigeria's independence, Kayode's childhood time and escape from his family from the war. An invitation to reflect on Western portraits of the African continent in frames that place it as the antithesis of Europe, a space without history, culture, and art. A shy invitation at the time, but urgent in contemporary times, which is averse to a strictly anthropological reading of the archives of Africanity, to the old and oppressive modes of appropriation of these archives, as a brutal strategy of dehumanizing the Other. 


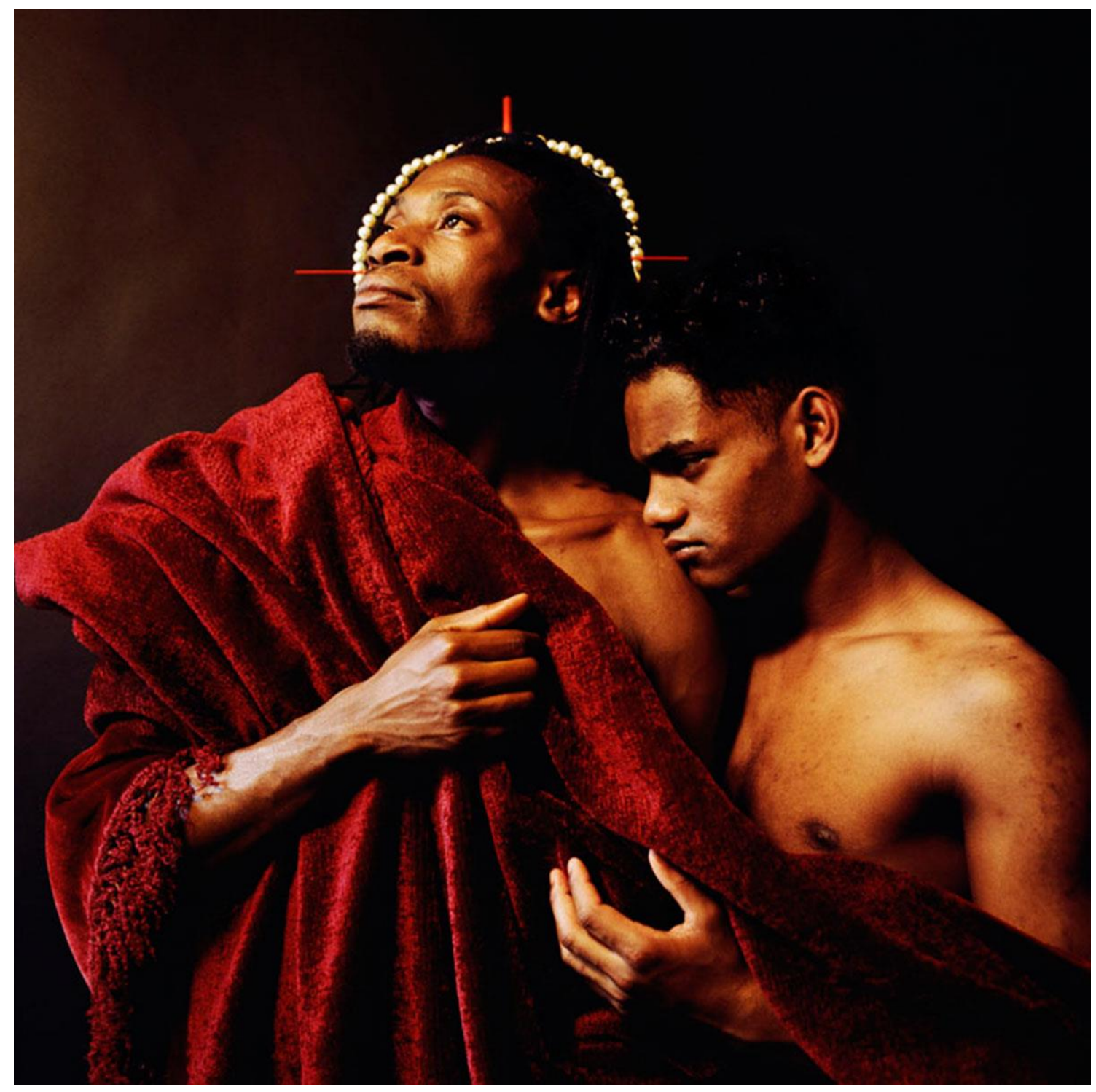

Figure 3: Rotimi Fani-Kayode, Every Moment Counts, 1989. ( ) Rotimi Fani-Kayode / Autograph ABP. Courtesy of Autograph ABP.

This imaginary distortion around the African continent is largely due to the education system set up in Africa by the West, as Fani-Kayode puts it:

The history of Africa and of the Black race has been constantly distorted. Even in Africa, my education was given in English in Christian schools, as though the language and culture of my own people, the Yoruba, were inadequate or in some way unsuitable for the healthy development of young minds (Fani-Kayode, 1996: 7). 


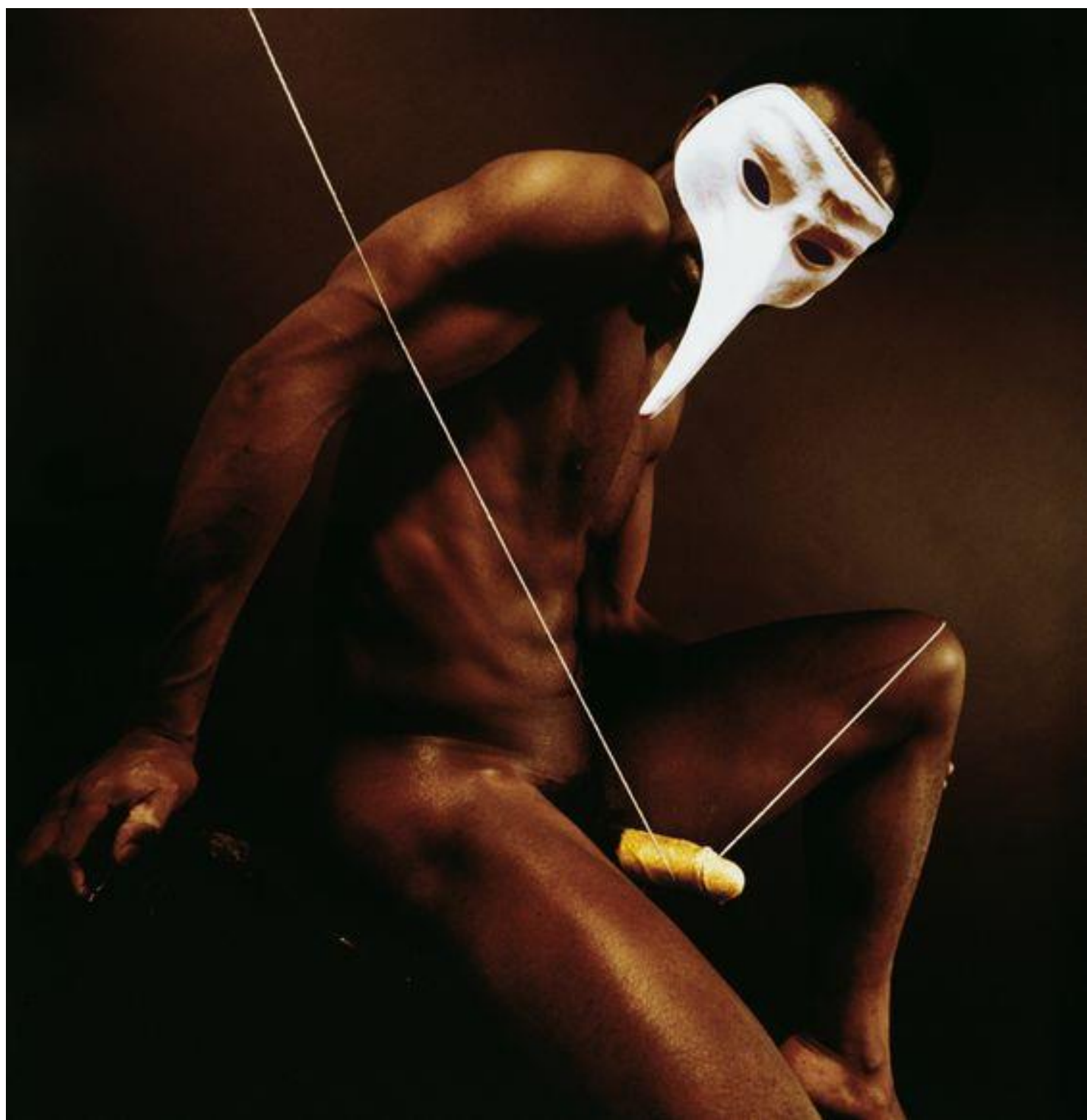

Figure 4: Rotimi Fani-Kayode, The Golden Phallus, 1989. @ Rotimi Fani-Kayode / Autograph ABP. Courtesy of Autograph ABP.

Nigeria's education system is derived from the late nineteenth century, when much of the rural population of colonial Nigeria migrated to urban centers and took over the educational process promoted by the missionaries. Nigerians took advantage of this education to socially ascend, considering that in 1890, with the import-export trade, it was necessary to read and write in English to find paid work (Falola \& Heaton, 2008). Moreover, the colonial administration was not interested in educating the peoples they exploited in Nigeria (Falola \& Aderinto, 2010), which justifies the metropolis' noninterference in the work of missionaries until a certain period. The hegemonic construction around the English language was a painful, slow and by no means a passive process. 
European education radically changed the culture of these peoples, who stood between native customs and European values. Since this education was so strongly rooted in Christianity, most of the Nigerians who received it assimilated the nineteenth and twentieth-century European values. The new assimilated beliefs also contributed to the anti-slavery cause that still ravaged much of native communities and to the idealization of a national conscience (Falola \& Heaton, 2008). If the Nigerian middle class took advantage of the gains of the British colonial regime, it also suffered from its exploitative base policy: the colonial norm viewed the African as an inferior, savage "race" that needed European oversight to maintain "order". That was enough to create in the imagination of this Nigerian middle class an idea that they were the link between the old and the new, the ancient and the modern, capable of disseminating the European "civilizing mission" and maintaining a connection with their ancestral culture.

In The Education of a British-Protected Child, Achebe (2009) highlights the emergence of the first university in Nigeria after World War I - Government College, in Umuahia, where he studied. His reflections lead us to realize how his choice for English literary writing was closely linked to the education of Nigeria and the institution of the modern Nigerian state. Both he and his predecessors and successors found themselves in the impasse between choosing the native or European language as vehicles to their literatures.

This is not to say that this impasse did not occur in French and Portuguese Africa, nor is it a denial of the tradition of oral culture that survives in these spaces, neither is a denial of the maintenance of native languages that stand out in Nigerian speech and literary production in these languages (Achebe, 1965). It should be borne in mind that "few black African states have the privilege of corresponding to a single traditional language community," which is why "almost every writer who sought to create a national tradition, transcending the ethnic divisions of the new African states, had to writing in European languages" (Appiah, 2014: 20).

Contrary to what some historians point out, Achebe emphasizes that the demand for English was not from the colonizer but from the native Nigerian peoples. As with Kenya and the rest of the British Empire, analogous to Falola \& Heaton (2008), Achebe (2012) states that demand for English in the Nigerian coastline already existed in the first half of the nineteenth century. In dialogue with J. F. A. Ajay, the writer shows us that in the Niger Delta in 1850, missionaries had to meet the demand of the language.

The use of English as a literary vehicle, contrary to popular belief, cannot be considered a "betrayal" of its ethnic group or those to whom its works are directed. Also questioned by the "choice" of language in her work, Nigerian writer Chimamanda Adichie took a 
stand on the fact and said she was not convinced that her writing in English was a "choice":

I'm not sure my writing in English is a choice. If a Nigerian Igbo like myself is educated exclusively in English, discouraged from speaking Igbo in a school in which Igbo was just one more subject of study (and one that was considered 'uncool' by students and did not receive much support from the administration), then perhaps writing in English is not a choice, because the idea of choice assumes other equal alternatives. Although I took Igbo until the end of secondary school and did quite well, it was not at all the norm. Most of all, it was not enough. I write Igbo fairly well but a lot of my intellectual thinking cannot be expressed sufficiently in Igbo. Of course this would be different if I had been educated in both English and Igbo. Or if my learning of Igbo had an approach that was more wholistic. The interesting thing, of course, is that if I did write in Igbo (which I sometimes think of doing, but only for impractical, emotional reasons), many lgbo people would not be able to read it. Many educated lgbo people I know can barely read Igbo and they mostly write it atrociously. I think that what is more important in this discourse is not whether African writers should or should not write in English but how African writers, and Africans in general, are educated in Africa (Adichie quoted by Azodo, 2008:2).

Although very focused on the Igbo portion of Nigeria, and in the images in general, Achebe and Adichie appear as Fani-Kayode interlocutors when the photographer speaks of this same fetish, of that same "primitive" character attributed to "being African". By taking as a point of interpretation, not only the geopolitics of the continent, but its art in general, especially when it came to be in fashion in European museums and under scrutiny because of the use of African masks made by their models in the photos.

According to Adichie (2008), there is a unique view of Africa, which is perpetuated through stereotypes around the hegemonic appropriation of the signs of Africanity. Because of colonial inheritance and slavery, Africa continues to be viewed by the West with inferior lens. This view of it gains new contours with the raciality printed in places where colonialism invented and perpetuated it, with the purpose of justifying its "civilizer" endeavor to exploit enslaved human beings. Printed also in literature (and the arts in general), these stereotypes make African characters "expendable". "Africans don't matter, not even in ostensibly narratives about Africa" (Adichie, 2008: 44).

Adichie emphasizes how easily these stereotyped images of Africa move from the artistic plane to the hegemonic media, particularly in the United States and Europe. The continent has been exposed in a frame in which Africans show themselves without vigor, gratitude or hunger, as misunderstood people, waging meaningless wars, drinking muddy water from rivers, dying of AIDS and being very poor (Adichie, 2008: 49).

Reflecting on Chinua Achebe's historical novel Things Fall Apart, almost fifty years after its release, Adichie describes how his work has been edited several times - both in Africa 
and in the United States - and has turned into a certain "Africa's anthropological treatise". This "artistic ethnography" eventually demands from Nigerian literature - and African art in general - a certain "authenticity".

Nigerian artists or artists of Nigerian origin are increasingly prominent on the international stage, given their constant transit conditions between Nigeria and the West. In 2005 , writer, dancer and photographer Taiye Selasi (1979-) coined the term "Afropolitanism" to characterize African artists who disseminate their art in contemporary diaspora. In the words of Selasi;

You'll know us by our funny blend of London fashion, New York jargon, African ethics, and academic successes. Some of us are ethnic mixes, e.g. Ghanaian and Canadian, Nigerian and Swiss; others merely cultural mutts: American accent, European affect, African ethos. (...) Not citizens, but Africans of the world (Selasi, 2005, March 3).

Similarly to Selasi, Teju Cole (1975-) sums it up: "Afropolitan, American, African. Whatever" (Cole quoted by Selasi, 2016, August 5). However, not all Nigerian artists share this idea. Okwunodu Ogbechi (2008, April 4), Binyavanga Wainaina (quoted by Santana, 2013, February 8) and Emma Dabiri (2014, January 21), for example, do not consider themselves as Afropolitans because of the term's relationship with the consumer industry.

Achille Mbembe (2007) brings a slightly more conciliative definition of the term, recognizing that African identities are fluid, as the African cultural past is marked by an imposed cultural combination. In opposition to consumption, Mbembe (2007) clarifies that the idea of "tradition" never existed and that there is a pre-colonial African modernity that must be considered. Thus, Mbembe (2007: 28-29) admits that

Afropolitanism is an aesthetic and poetic of the world. It is a way of being in the world, refusing on principle any form of victim identity - that does not mean that it is not aware of the injustice and violence inflicted in the continent and its people by the law of the world. It is also a political and cultural stance in relation to the nation, to race and to the issue of difference in general.

Although photographer Rotimi Fani-Kayode lived and produced his art long before the term "Afropolitanism" was forged, we highlight the importance of positioning the artist in this political discourse. Such a perspective is very contemporary and has been discussed in academia from various points of view. We want to state that Fani-Kayode fits into an Afropolitan movement in the broadest sense, just as it employs Mbembe (2007). This does not imprison his art in the European mainstream, nor does the relegation to permanent victimization, if viewed by Western hegemonic reading. On the contrary - it is free of any identity ties. 
Fani-Kayode reports the insertion of his photographs in Europe and how the reception of his photography impacts the reading of those who have African art as an exotic and primitive object to be read:

My reality is not the same that which is often presented to us in western photographs. As an African working in a western medium, I try to bring out the spiritual dimension in my pictures so that concepts of reality become ambiguous and are opened to reinterpretation. This requires what Yoruba priests and artists call a technique of ecstasy. (...) I make my pictures homosexual on purpose. Black men from the Third World have not previously revealed either to their own peoples or to the West a certain shocking fact: they can desire each other. (...) It is now time for us to reappropriate such images and to transform them ritualistically into images for our own creation (Fani-Kayode, 1996: 6).

A dissident appropriation of the same archive or collection of Africanity produces strategies of resistance and empowerment for a part of the British population, who wants to be recognized as migrant, Nigerian, black, mixed race and queer.

In times that guarantee the legislation to ban homosexual marriage in Nigeria, we gay and African descendants insist on the questions: How to fight in the war for the possession of the body from the dismantling of these forces? How to detach identity from body enclosure and representational confinement?

When Chinua Achebe (1998: 1) said in The Trouble with Nigeria that his country's problem is "leadership failure," it was not simply intended to criticize the alternations between military dictatorial regimes and elected and corruption-ruled governments. The writer's frustration was the same as Fani-Kayode's - both suffered from the Biafra War and the pain of exile. The same frustration was shared by the fact that getting rid of the passport granted by the British Protectorate ${ }^{3}$ was not the only thing that would contribute to the development of Nigeria. The desire of the photographer and writer for the development of their country would not be easily attained due to the very pre-colonial condition of what would be called "Nigeria": a tangle of over 200 ethnic groups, ruled by local leaders and that could not recognize each other either in language, nor religion or culture.

The states of Kanem-Borno, Benin, Oyo, and the Sokoto Caliphate were large in size and centralized, before the British empire designed a new geography and instituted a new notion of territory in those spaces, with the junction of the North and South protectorates in 1914. Other states were smaller and more decentralized, coordinated

\footnotetext{
${ }^{3}$ Achebe (2009: 14) reports that before he had a Nigerian identity, he was traveling with a passport designating him as "Person under the British Protectorate".
} 
by local chiefs or elites. Territorial boundaries were delimited and redrawn long before 1960, when independence occurred (Oyebade, 2003).

Another factor that also contributed to Fani-Kayode and Achebe's frustration was the establishment and adaptation of political institutions in Nigeria by the British Empire, between the 19th and 20th centuries, which had direct links with these same "heads of state". The British system maintained them, in exchange for local power and prestige, but under the authority of the Empire (Oyebade, 2003). According to Falola \& Heaton (2008), the colonial organization in Nigeria altered its political landscape in two ways: first, it brought about the union of different groups that organized themselves autonomously. Second, the indirect rule process no longer allowed local leaders access to sovereignty over their villages, and also the general lack of understanding of the ways the states organized themselves before the invasion (Falola \& Heaton, 2008: 8-9).

Later, with colonial and economic expansion, the British Empire assigned Englishspeaking and educated Nigerians in Europe to perform administrative tasks that required closer contact with the colony back then. It was these same European-educated "Nigerians" who mobilized the nationalist movements for independence after World War II. What Achebe did not know, a man of his time, was that the "goal of a developing nation like Nigeria" - "modernization" - would not be achieved with its territorial cartography within colonial molds (Achebe, 1990: 151). It was the permanence of this junction, regulated this time by the nation-state, that caused much of the conflicts we are witnessing today in these spaces. Wole Soyinka, in a recent statement, stressed that

\begin{abstract}
it was obvious at the time of independence that Nigeria was trying to reconcile many contradictions, and this could pose problems. Some say this was obvious from the time of colonization, when very different groups were arbitrarily assembled in one country, regardless of their history, economy and culture. It would not be easy to erase these contradictions with the mere creation of a state. I hate to say "I warned you," but it's true. I warned, warned and warned (Soyinka quoted by Freitas, 2015, 31 $1^{\text {st }}$ January)
\end{abstract}

Since then, the Nation-state cannot contain the new cartographies that have been shaped in Nigeria. "The imagined nation, the place that they would like to see as their own space, [...] outside the control of the national State" (Appadurai, 1997: 40) would be restricted to the plane of imagination.

At its embryonic stage, Nigeria had three major regions and the federal capital in Lagos, transferred in 1991 to Abuja; in 1967, it was divided into 12 regions, 19 in 1976, 21 in 1987 and 30 in 1991. Since 1996, Nigeria has been divided into 36 regions, which does not prevent minority ethnic groups from claiming the emergence of other regions (Oyebade, 2003). 
Nigeria had its last president, "Muslim" Muhammadu Buhari, elected in 2015. This is the first time it has been so long under civil representation. Since independence, various ethnic-religious conflicts have caused uncontrollable social instability in the country. At the federal level, Southern Christians fear being overwhelmed by Northern Muslims; on a smaller territorial scale, ethnic minorities fear the dominance of larger ethnic groups: the Hausa-Fulani in the North, the Yoruba in the Southwest and the lgbo in the Southeast (Falola \& Heaton, 2008).

These tensions resulted in the Biafra War from 1967 to 1970. Ethnic-religious conflicts continue to emerge, without the Nigerian state being able to soften them. Another factor contributing to the state's non-intervention in these conflicts is the high rate of corruption in the Nigerian public administration. Using conflict and corruption as reasons, several military coups took place in Nigeria. In its first 40 years of existence as a nation state, Nigeria was 28 years under military rule. Three of the coups were in exchange for replacing one military regime with the other and two others to replace civilian regime (Siollun, 2009).

The 2015 elections, the fifth since 1999, had symbolic value in Nigerian history: it was the first time that the opposition, in the person of Muhammadu Buhari, had had any chance to rise to power and replace the People's Democratic Party (PDP) supremacy. For the first time, an opposing group emerged from the junction of three different parties, ethnic groups, and regions. The All Progressive Congress (APC), which opened in 2013, stood as the hope of equal competition and the achievement of difference-based government.

In addition to its democratic role, the 2015 election had another meaning for Nigeria: its maintenance as a means of resisting terrorism by Boko Haram. Tensions caused by the terrorist group are estimated to have caused the internal displacement of 650,000 people in August 2014 (Adibe, 2015). According to estimated data, there are more than 100,000 Nigerians seeking refuge in Diffa, the border city between Nigeria and Southeast Niger since early 2014, 44,000 refugees in Cameroon and 2,700 in $\mathrm{Chad}^{4}$ (Adibe, 2015).

The Nigerian nation state, which basis is the forced annexation of multiple territories, witnesses its diverse ethnic nuances being spread within and outside the African continent. The difference is that these "ethnic identity maps" only converge on "national

\footnotetext{
${ }^{4}$ The deaths caused by ethnic-religious conflicts at the present time give new contours to the conflicts that already existed in Nigeria. Christians and Muslims in northern Nigeria are constantly threatened. In the South, and especially in the Niger Delta, there is strong activity by militias and pirate attacks on coastal areas, as well as kidnappings. Due to high levels of violence and poverty, Nigeria's image as a country plagued by poverty and ethnoreligious conflict has been strengthened internationally, although efforts are being made to overcome the situation. See Akinola (2013: 12-13).
} 
identity maps" when they cross borders and come across other cartographies. In Nigeria, ethnicity generates the territory.

If Fani-Kayode was still alive, he would see that the expectations of the Nigerians were not met. In the words of Chimamanda Adichie (2016, October 18), the beginning of Muhammadu Buhari's term could be translated as Nigeria's Failed Promises, because 30 years after Buhari's government as head of state, Nigeria had the opportunity to more democratically elect a president. Buhari had become a form of hope (Adichie, 2016, October 18). His delays in pinpointing strategies for economic improvement, the steady decline in oil prices, the rise in subsistence commodities, and the strengthening of the black market surrounding the sale of international currency in the country mark his government's rooting in an "outdated economic model and an infantile view of Nigerians. For him, it seems, patriotism is not a voluntary and flexible thing, with room for dissent, but a martial enterprise: to obey without questioning. Nationalism is not negotiated, but enforced" (Adichie, 2016, October 18).

Even in this context, Rotimi Fani-Kayode urges us to see beyond the problems facing contemporary Nigeria and Western reading of African arts in diaspora. The Nigerian photographer points to protagonist images of Africans and African descendants in the constitution of Western history. The Traces of Ecstasy exhibition, held in South Africa in 2016, comes to light at the end of a tunnel where Fani-Kayode still shines as a reference in the struggle of African artists based in Europe in an attempt to review the meanings imposed on their bodies, the space in which they live, to tear down monuments and stories of oppression. Despite their still insipient visibility, contemplating such photographs may prompt us to think of our distance from Kayode's "Africa" but also somehow bring it closer to ours.

Getting out of the interpretative enclosure of the pictorial and ethnographic predictability can pave the way for us to dissociate the African Diaspora arts from the overload of identity representation, the "Negro type", and the enclosure of the body, elucidated by the question that initiates the article. Images like Rotimi Fani-Kayode's that defy the official archive offer no meaning, but the challenge of reading Africa's visual culture in diaspora beyond identity stability, offering these images the possibility of displaying their plastic force, their anachronistic condition, which resists and frees themselves from the imprisonment of memory linked to slavery. 


\section{References}

Achebe, C. (1965). English and the African Writer. Transition, 18, 1783-1794.

Achebe, C. (1998). The Trouble with Nigeria. Lagos: Fourth Dimension Publishing Company.

Achebe, C. (2009). The Education of a British-Protected Child. New York: Anchor Books.

Achebe, C. (1990). What Literature Has Got To Do With It?. In Achebe, C. (Ed.), Hopes and Impediments: Selected Essays (pp. 154-170). New York: Anchor Books.

Adibe, J. (2015). The 2015 Elections in Nigeria: the issues and challenges. In Adibe et al, Foresight Africa: Top Priorities for the Continent in 2015 Report (pp.3-9). Washington DC: The Brookings Institution, Africa Growth Initiative. Retrieved from: https://www.brookings.edu/wp-content/uploads/2016/07/foresight-africa-full-report-

FINAL.pdf

Adichie, C. N. (2008). African "Authenticity" and the Biafran Experience. Transition, 99, 42-58. doi: 10.2979/TRS.2008.-.99.42

Adichie, C. N (2016, October 18). Nigeria's Failed Promises. The New York Times. Retrieved from: https://www.nytimes.com/2016/10/19/opinion/chimamanda-ngoziadichie-nigerias-failed-promises.html

Azodo, A. U. (2008). Interview with Chimamanda Ngozie Adichie: Creative Writing and Literary Activism. Retrieved from: http://citeseerx.ist.psu.edu/viewdoc/download?doi=10.1.1.551.6641\&rep=rep1\&type $=p$ df

Akinola, O. (2013). The Rebirth of a Nation: Nollywood and the Remaking of Modern Nigeria. The Global South, 7(1), 11-29. doi: 10.2979/globalsouth.7.1.11

Appadurai, A. (1997). Soberania sem territorialidade: notas para uma geografia pósnacional. Novos Estudos, 49, 33-46.

Appiah, K. A. (2014). Na casa de meu pai: a África na filosofia da cultura. Rio de Janeiro: Contraponto.

Akinwotu, E. (2018, March 30). Blackmail, prejudice and persecution: gay rights in Nigeria. The Guardian. Retrieved from: https://www.theguardian.com/globaldevelopment/2018/mar/30/blackmail-prejudice-persecution-gay-rights-nigeria.

Coates, T. (2015). Between the World and me. New York: Random House.

Dabiri, E. (2014, January 21). Why I'm not an Afropolitan. Africa is a Country. Retrieved from: http://africasacountry.com/2014/01/why-im-not-an-afropolitan/

Falola, T. \& Heaton, M. M (2008). A History of Nigeria. London: Cambridge University Press.

Falola, T. \& Aderinto, S. (2010). Nigeria, Nationalism, and Writing History. New York: University of Rochester Press.

Fani-Kayode, R. (1996). Traces of Ecstasy. In Fani-Kayode, R. and Hirst, A. (Eds.). Photographs (pp. 4-11). London: Autograph. 
Freitas, G. (2015, January 31). Dramaturgo nigeriano Wole Soyinka, ganhador do Nobel, alerta para 0 avanço do Boko Haram. $O$ Globo. Retrieved from: http://oglobo.globo.com/cultu-ra/livros/dramaturgo-nigeriano-wole-soyinka-ganhadordo-nobel-alerta-para-avanco-do-boko-haram-15201203

Mbembe, A. (2007). Afropolitanism. In Simon, N. (Ed.), Africa Remix: Contemporary Art of a Continent (pp. 26-30). Johannesburg: Jacana Media.

Matos, P. F. (2014). A fotografia na obra de Mendes Correia (1888-1960): modos de representar, diferenciar e classificar da "antropologia colonial". In Vicente, F. L. (Ed.), O Império da Visão: fotografia no contexto colonial português (1860-1960) (pp. 45-66). Lisbon: Edições 70.

Mercer, K. (1996). Eros \& Diaspora. In Fani-Kayode, R. \& Hirst, A (Eds.), Photographs (pp. 108-121). London: Autograph.

Ogbechi, O. (2008, April 4). "Afropolitanism": Africa without Africans. AACHRONYM Global African Arts with a focus on art-equity and cultural patrimony. Retrieved from: http://aachronym.blogspot.com/2008/04/afropolitanism-more-africa-without.html

Oyebade, A. (2003). A Retrospect on Colonial Nigeria. In Oyebade, A. (Ed), The Foundations of Nigeria: Essays in honor of Toyin Falola (pp. 1-15). Asmara: Africa World Press.

Santana, S. (2013, February 8). Exorcizing Afropolitanism: Binyavanga Wainaina explains why "I am a Pan-Africanist, not an Afropolitan" at ASAUK 2012. AiW African in Words. Retrieved from: https://africainwords.com/2013/02/08/exorcizing-afropolitanismbinyavanga-wainaina-explains-why-i-am-a-pan-africanist-not-an-afropolitan-at-asauk2012/

Selasi, T. (2005, March 3). Bye-Bye Babar. The Lip. Retrieved from: http://thelip.robertsharp.co.uk/?p=76

Selasi, T. (2016, August 5). Teju Cole talks to Taiye Selasi: 'Afropolitan, American, African. Whatever'. The Guardian. Retrieved from: https://www.theguardian.com/books/2016/aug/05/teju-cole-taiye-selasi-interviewknown-strange-things

Siollun, M. (2009). Oil, Politics and Violence: Nigeria's Military Coup Culture (19661976). New York: Algora Publishing.

Steel, R. (2016, December 28). Nigerian Photographer Rotimi Fani Kayode: Exposing Prejudice Through the Nude. The Culture Trip. Retrieved from: https://theculturetrip.com/africa/nigeria/articles/nigerian-photographer-rotimi-fanikayode-exposing-prejudice-through-the-nude/

UNHCR, United Nations High Commissioner for Refugees. (2019). Perfil das Solicitações de Refúgio relacionadas à Orientação Sexual e à Identidade de Gênero. Retrieved from: https://datastudio.google.com/reporting/11eabzin2AXUDzK6_BMRmobAIL8rrYcY/page/1KIU 
Jânderson Albino Coswosk is Professor of Basic, Technical and Technological Education in the Department of Languages at the Federal Institute of Espírito Santo, Brazil. He is a Ph.D. candidate at State University of Rio de Janeiro (UERJ) in Literary Studies and is currently a Visiting Scholar at Dartmouth College. His research deals mainly with James Baldwin's oeuvre and its contemporary dialogues with visual culture, as well as its impacts in Brazil.

凶jandersoncoswosk@gmail.com 